\title{
ARTYKUŁY
}

\section{Chong-Pin Lin}

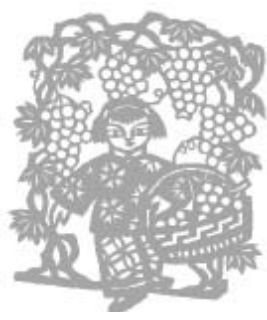

\section{FORMUJACCA SIĘ WIELKA STRATEGIA CHIN: (KU DOMINACJI W AZJI WSCHODNIEJ, ALE BEZ WALKI) ${ }^{1}$}

Od drugiej połowy 2002 r. władze w Pekinie krok po kroku wdrażają koncepcję zintegrowanej wielkiej strategii ${ }^{2}$. Porządkuje ona w sposób całościowy politykę wewnętrzną i zagraniczną oraz politykę względem Tajwanu, tworząc układ elementów wspierających się wzajemnie na zasadzie synergii. Dzięki niej Pekin osiaggnął już znaczne sukcesy $\mathrm{w}$ polityce zagranicznej, i to pomimo fundamentalnych dylematów stojących przed Chinami w polityce wewnętrznej. Wraz z wyrastaniem na mocarstwo coraz wyraźniej podtrzymujące status quo, kraj ten napotyka jednak nieznane dotąd wyzwania. Jedną z głównych ambicji Pekinu w ramach owej wyłaniającej się koncepcji bezpieczeństwa narodowego - choć oficjalnie się o tym nie wspomina - jest zyskanie dominacji w Azji Wschodniej, przez pozbawienie Stanów Zjednoczonych ich przywódczej roli w tym regionie. A zamierza się to osiagnąć bez wojny, za pomocą kultury i gospodarki. Intensywnie modernizowany chiński potencjał militarny powinien, według Pekinu, być w pełni przygotowany do użycia, choć - w miarę możności - nigdy nie powinien zostać użyty (bei er bu yong) w prawdziwej walce. Przede wszystkim jednak Pekin chce wzmacniać oddziaływanie środków pozamilitarnych będących w jego dyspozycji³ .

1 Wykład wygłoszony 31.10.2006 w Pilznie, na Uniwersytecie Zachodnich Czech, podczas konferencji naukowej na temat „Dylematy współczesnego bezpieczeństwa: uwagi na temat bezpieczeństwa w Europie Środkowej i Azji Wschodniej”. Został on także przedstawiony w SWPS, 14 listopada $2006 \mathrm{r}$.

2 Termin ,wielka strategia” oznacza tu taką strategię, w ramach której komponent czysto militarny jest jednym z wielu - obok politycznego, ekonomicznego, czy innych, pozamilitarnych.

3 Termin „pozamilitarne” odnosi się tu do takiego aspektu charakterystyki owych środków, który wykraczając poza wymiar czysto militarny nie wyklucza jednocześnie z ich definicji efektów działań militarnych. Środki pozamilitarne obejmują działania polityczne o charakterze dyplomatycznym, ekonomicznym, kulturalnym, psychologicznym, prawnym, a także politykę medialną. 
8 listopada 2002 r. w Radzie Bezpieczeństwa ONZ miało się odbyć głosowanie w sprawie inspekcji badającej kwestię posiadania broni masowego rażenia przez Irak, a w istocie - nad poparciem dla amerykańskiej inwazji na ten kraj. Spodziewano się sprzeciwu Chin - wcześniej władze w Pekinie bardzo zdecydowanie wypowiadały się bowiem przeciwko „hegemonii” i ,uderzeniom prewencyjnym” w odniesieniu do wojny w Afganistanie rozpoczętej przez Stany Zjednoczone pod koniec $2001 \mathrm{r}$.

Okazało się jednak, że Pekin tym razem nie głosował przeciw. Nie wstrzymał się nawet od głosu, ale poparł tę decyzję. Była to pierwsza publiczna odsłona tego, co nazywam właśnie nową wielką strategią Pekinu.

Nasuwa się $\mathrm{w}$ związku z tym szereg pytań. Jakie były przesłanki obrania przez Zhongnanhai ${ }^{4}$ nowego kursu? Jak rozwijała się owa wielka strategia? Jakie elementy ją tworzą? Jakim instrumentarium posługuje się ona? Jakie kalkulacje kryje? Czym się charakteryzuje chińska wielka strategia? W jaki sposób przejawia się ona w stosunkach z USA, Japonią i Tajwanem? Jakiego rodzaju wyzwania stawia przed Pekinem jej wprowadzanie? Jakie są jej implikacje? I wreszcie: jakie wnioski możemy z niej wysnuć?

\section{FORMOWANIE: JAK ZRODZIŁA SIĘ NOWA STRATEGIA? Dalekowzroczna propozycja Qian Qichena}

W styczniu 2001 r., bądź niewiele wcześniej, wicepremier ChRL, Qian Qichen, podczas kilku wewnętrznych narad wyrażał pogląd, że w stosunkach z Waszyngtonem należy przedkładać współpracę nad wyrażanie sprzeczności interesów ${ }^{5}$. Wkrótce potem - 1 kwietnia - nad Morzem Południowochińskim miał miejsce pamiętny incydent lotniczy, który niewątpliwie na jakiś czas zdezaktualizował tę propozycję, a jej autor musiał wykazać się dużą odpornością psychiczną wobec narastającej w szeregach Chińskiej Armii Ludowo-Wyzwoleńczej (ChALW) fali nastrojów anty-amerykańskich. Mniej więcej latem 2002 r. w Zhongnanhaiu osiagnięto konsensus na miarę nowej epoki w dwóch fundamentalnych kwestiach. Pierwszą było przyjęcie dalekowzrocznej propozycji Qian Qichena, drugą - dokonanie roszady kluczowych priorytetów: „rozwój gospodarczy Chin" postawiono przed „zjednoczeniem ojczyzny”.

4 Zhongnanhai - zespół budynków w Zakazanym Mieście (dawnym pałacu cesarskiego w Pekinie), stanowi obecnie rezydencję najwyższych władz państwowych i partyjnych ChRL (red.).

5 Informacja pochodzi z kręgów rządowych w Tajpej.

6 Informacja pochodzi z kręgów rządowych w Tajpej. Hu Jintao powiedział na spotkaniu z tajwańską diasporą w Brazylii (14.11.2004): „aby Chiny stały się silne..., musimy najpierw się rozwinąć (gospodarczo), a potem zjednoczyć...” „Yazhou Xinwenwang” (Asian Newsnet) z 14.11.2004. 
W lipcu 2002 r., Qian, wzywając władze w Tajpej do podjęcia negocjacji w sprawie „trzech połączeń”, nie wspomniał o kwestii ,jednych Chin”, jakich uznanie było dotychczas warunkiem wstępnym do podjęcia rozmów przez Pekin ${ }^{8}$. Gdy 3 sierpnia tajwański prezydent Chen Shui-bian publicznie określił stosunki Tajwanu z kontynentem (tzw. „stosunki poprzez Cieśninę”), jako relacje „dwu państw po obydwu stronach”, Pekin, wbrew swej dotychczasowej praktyce, powstrzymał się od ostrej reakcji, wspierając nadal współpracę gospodarczą̧. We wrześniu minister spraw zagranicznych ChRL Tang Jiaxuan złagodził rygory trzyczęściowej definicji „zasady jednych Chin”10.

W październiku 2002 r., w artykule opublikowanym w jednym z najważniejszych czasopism Komunistycznej Partii Chin (KPCh), Qian wyjaśniał następująco logikę nowego podejścia do stosunków z USA, przygotowując niejako swoich czytelników na zaskakujące głosowanie w ONZ. Pisał on:

„Zupełnie nie wystarczy mieć tylko rękę gotową do toczenia walk. Równie ważne jest wyciagganie ręki do współpracy. A przecież współpraca sama przez się jest ważnym czynnikiem ograniczającym pole manewru anty-chińskich sił w Stanach Zjednoczonych"11.

\section{Nowe emploi władz w Pekinie}

Kolejne lata miały przynieść jeszcze więcej niespodzianek ze strony Pekinu a stanowily one całkowite novum.

W początkach sierpnia 2003 r., Chiny zaprosiły obce wojska do przeprowadzenia ćwiczeń anty-terrorystycznych na „Świętej ziemi ojczystej”. W tym samym miesiącu obserwatorom z 15 państw pozwolono przyglądać się manewrom ChAL-W (w 2004 r. ich

7 Chodzi o morskie, lotnicze i pocztowe połączenia Tajwanu z kontynentem. Do 2000 r., kiedy to uruchomiono tzw. „małe połączenia” z przybrzeżnymi wyspami, wciąż obowiązywały zasady blokady z okresu zimnej wojny. Wszystkie połączenia Tajwanu z kontynentem mogły dochodzić do skutku tylko przez kraje trzecie, najczęściej Hongkong. Szczególna gorliwość w egzekwowaniu tych zakazów aż do niedawna cechowała stronę tajwańską, obawiającą się ,infiltracji komunistycznej" (red.).

s. 1.

Qian Qichen: tan santong kebushe yizhong - „Lienhebao” (United Daily News) z 6.07.2002,

9 Zhonggong duitai zhengce yi fazhan daitiduikang wei zhongzhou - ,Zhongguoshibao” (China Times) z 9.09.2002, s. 1 .

10 Tan Jiaxuan zai lianda ti yizhong xin sanduan lun - „Lienhebao” z 15.08.2002, s. 4. Nowe sformułowanie brzmiało: „na świecie są tylko jedne Chiny; część kontynentalna i Tajwan tak samo należą do jednych Chin; integralność chińskiej suwerenność i terytorium nie może być naruszona”. Natomiast wersja poprzednia była następująca: „na świecie są tylko jedne Chiny; Chińska Republika Ludowa jest jedynym legalnym rządem reprezentującym Chiny; Tajwan jest częścią Chin".

${ }_{11}$ Qian Qichen, Jiu-shiyi shijian houde guojixingshi he Zhong Mei guangxi [The Post-September 11 International Situation and Sino-U.S. Relations], „Xuexi Shibao” (Study Times), Beijing: The Central Party School, October 2002, (materiał do użytku wewnętrznego). 
liczbę zwiększono do 16). W październiku, Chiny przeprowadziły pierwsze ćwiczenia ratownictwa morskiego z udziałem innego państwa - był nim Pakistan (po nim - Francja i inne kraje). Nieco wcześniej, w maju i czerwcu, Pekin podjął rozmowy z Moskwą i New Delhi, mające ostatecznie rozwiązać spory graniczne, które w przeszłości stały się przyczyną zbrojnych starć (odpowiednio w 1962 i w 1969 r.). W listopadzie, Pekin po raz pierwszy od 1949 roku „umiędzynarodowił” kwestię tajwańską rozsyłając do ponad stu siedemdziesięciu ambasad oświadczenie, zawierające streszczenie chińskiego stanowiska wobec Tajwanu, co wiązało się z pomysłami Tajpej przeprowadzenia referendum w kwestiach związanych z niepodległością i wprowadzenia zmian do konstytucji ${ }^{12}$.

Ten sam kierunek był kontynuowany w 2004 r. W listopadzie, premier ChRL Wen Jiabao, podpisując porozumienie handlowe ze Stowarzyszeniem Narodów Azji Południowo-Wschodniej (ASEAN), wyraził poparcie dla wysuwanej przez ASEAN od dawna koncepcji utworzenia strefy bezatomowej ${ }^{13}$ (choć chiński potencjał nuklearny nie przestawał rosnąć) $)^{14}$.

W kwietniu 2005 r. dokonał się przełom w stosunkach między obu państwami chińskimi - w Pekinie doszło do historycznego spotkania między przywódcami KPCh i Kuomintangu: Hu Jintao i Lien Zhanem, stojącymi na czele sił politycznych, które przez większą część ubiegłego pozostawały ze sobą w śmiertelnym konflikcie.

\section{ZAŁOŻENIA NOWEJ STRATEGII}

Elementy wielkiej strategii: od spraw wewnętrznych do polityki globalnej.

Wdrażana przez Pekin nowa wielka strategia łączy sześć grup zadań, których znaczenie można, jak się zdaje, uszeregować w następującym porządku:

1. Unieszkodliwienie „,bomb z opóźnionym zapłonem”, którymi wewnątrz kraju są rozprzestrzeniające się niepokoje społeczne i coraz większe nierówności ekonomiczne, a służyć to ma utrzymaniu za wszelką cenę stabilności kraju.

2. Wzmocnienie i instytucjonalizacja oficjalnych kanałów porozumiewania się z Waszyngtonem, chociaż bez powstrzymywania się od wyrażania różnic poglądów. Dwustronna współpraca powinna mieć jednak priorytet w stosunku do sprzeczności interesów. Należy też unikać militarnej konfrontacji z USA.

3. Najbardziej pożądaną opcją względem Tajwanu jest ,aneksja bez walki”. Średnią opcją jest ewentualne „ograniczone uderzenie perswazyjne”, jakie też należy przygotować. Najgorszym rozwiązaniem byłby natomiast wariant ,zajęcia Tajwanu przy

12 Obecnie obowiązująca konstytucja Republiki Chińskiej (na Tajwanie) została przyjęta w 1946 r., jeszcze przed wojną domową w wyniku której jej kuomintangowski rząd musiał się schronić na Tajwanie po przegranej kampanii. Ogłoszenie niepodległości Tajwanu wymagałoby zatem najpierw zmiany tej konstytucji i granic „terytorium narodowego” (red).

13 Po raz pierwszy zgłoszono ją w 1971 r. (red.).

14 Jane Perlez, Beijing Signs Pact for ASEAN Trade: China Promises Good Behavior in Region and Support for Nuclear Arms-free-zone, „International Herald Tribune” z 30.11.2004, s. 1, 8. 
odstraszeniu Stanów Zjednoczonych" (od interwencji - red.). Należy tu dodać, że wariant „uderzyć na USA i zniszczyć Tajwan” nie był w ogóle rozważany ${ }^{15}$.

4. Aktywne wdrażanie „polityki dobrosąsiedzkiej” w stosunku do państw otaczających, mającej zapewnić każdemu $\mathrm{z}$ sąsiadów poczucie przyjaźni i bezpieczeństwa, a także przyczyniania się do jego wzrostu dobrobytu (mulin, anlin, fulin).

5. Rozwijanie stosunków z Unią Europejską jako przeciwwagi wobec Stanów Zjednoczonych.

6. Umacnianie obecności Chin w Afryce i Ameryce Łacińskiej poprzez „politykę surowcową". Zakupy ropy, surowców mineralnych i drewna powinny stać się skutecznymi narzędziami polityki zagranicznej oraz pomocy gospodarczej.

\section{Instrumentarium: ChALW, gospodarka i kultura}

W nowej wielkiej strategii Pekinu instrumenty ekonomiczne i te $\mathrm{z}$ dziedziny polityki kulturalnej są wyraźnie eksponowane, podczas gdy skrywa się wysiłki nabywania zaawansowanych technologii militarnych. Chodzi o to, by przemawiać łagodnie, za plecami chowając porządny kij - jak w słynnym powiedzeniu Teddy"ego Roosevelta. Pekin chciałby grać raczej w chińską grę „go" (jap., chińskie weiqi), niż w szachy. $\mathrm{W}$ tej pierwszej grze, kolejne ruchy budzą o wiele mniej niepokoju po stronie przeciwnika i są mniej wyzywające, niż w tej drugiej. W szachach bowiem jedna strona jest często stawiana w stan najwyższej gotowości przez przeciwnika przez nadchodzące zagrożenia, podczas gdy w „go" można przegrać nie podejrzewając tego aż do ostatniej chwili, kiedy gra okazuje się zakończona.

Rozpatrując kwestię modernizacji ChALW należy zwrócić szczególną uwagę na trzy kwestie. Pierwsza - to odstraszanie nuklearne. Można sobie wyobrazić, że gdy łodzie podwodne o napędzie atomowym typu 094, z których każda może wystrzelić 16 międzykontynentalnych wielogłowicowych rakiet balistycznych wejdą do służby w chińskiej marynarce wojennej - co nastapi w najbliższej przyszłości - Waszyngton będzie musiał zastanowić się dwa razy, czy interweniować zbrojnie w razie sprowokowanego przez ChALW militarnego kryzysu w Cieśninie Tajwańskiej.

Zagadnienie drugie to zdolność do przeprowadzenia swoistej „wojny akupunkturowej”, czyli operacji paraliżującej obronę Tajwanu, w wyniku której ChALW zajęłaby wyspe przy minimalnym przelewie krwi i zniszczeń. Odpowiednie wyposażenie $\mathrm{w}$ dziedzinie broni i logistyki potrzebne do takiego uderzenia będzie najprawdopodobniej gotowe tuż po 2010 roku.

15 Te założenia strategiczne wywodzą się z teorii Sunzi osiagania zwycięstwa ale bez walczenia, fascynującej obecnie dowódców chińskich. Patrz analiza: Yu Zeyuan, Jiefangjun yanjiu Sunzi bingfa ying dui Tai weiji [People"s Liberation Army Studies Sun Tzu the Art. of War to Cope with the Taiwan Strait Crisis], „Lienhe Zaobao” (United Morning News), 13.10.2006. 
Trzecia kwestia wiąże się z chińską marynarką wojenną. Tempo jej szybkiego rozwoju w ostatnich latach - zarówno dzięki produkcji krajowej, jak i zakupom dokonywanym zagranicą - budzi coraz większe zaniepokojenie. Wtargnięcie chińskiej łodzi podwodnej o napędzie atomowym na japońskie wody terytorialne w listopadzie 2004 r. było tylko symptomem zachodzących przemian w sferze bezpieczeństwa w całym regionie. W drugiej połowie października 2006 r., rosyjskie źródła podały, że Chiny prawdopodobnie zakupią 50 myśliwców typu Suchoj-33, przystosowanych do użycia z pokładu lotniskowca. Być może Chiny szykują się do przebudowy lotniskowca „Varyag” kupionego od Ukrainy w $1999^{16}$.

Jako partner handlowy Stanów Zjednoczonych, Chiny spowodowały po raz pierwszy w 2003 r. osiagnięcie przez ten kraj najwyższego poziomu deficytu handlowego $\mathrm{w}$ jego historii. Wyprzedziły również w tym samym roku Stany Zjednoczone stawszy się największym partnerem handlowym Unii Europejskiej, rok później to samo osiagnęły wobec Japonii i Korei Południowej. Pod względem wielkości gospodarki, oczekuje się, że Chiny wyprzedzą Japonię do 2015 r., a Stany Zjednoczone - do $2040 \mathrm{r}^{17}$. Świadomość tego stanu rzeczy po stronie partnerów zagranicznych niewątpliwie umacniała status międzynarodowy Chin i zwiększała pole manewru chińskiej dyplomacji. Na przykład, napięcie między Chinami i Japonią z wiosny 2005 r. zakończyło się dość dramatycznie: przeprosinami japońskiego premiera Koizumiego, najprawdopodobniej z powodu narastającego uzależnienia ekonomicznego Japonii od Chin.

Pekin stara się ponadto promować w świecie wizerunek Chin, jako centrum aktywności gospodarczej na przyszłość posługując się tak środkami z zakresu kultury wysokiej, jak i popularnej. Oto przykłady:

- sponsoring międzynarodowych konkursów piękności;

- organizacja prestiżowych imprez sportowych, takich jak wyścigi Formuły 1, mecze koszykówki drużyn z ligi NBA, mecz piłki nożnej z udziałem Realu Madryt;

- przyciaganie czołowych projektantów mody;

- promowanie nauki języka chińskiego jako języka obcego;

- tworzenie sieci centrów kultury chińskiej - Instytutów Konfucjusza - w ważniejszych metropoliach świata ${ }^{18}$

- wysyłanie za granicę rzesz chińskich turystów wydających tam swobodnie znaczne sumy;

- organizacja prestiżowych konferencji naukowych, np. Forum Pekińskie, zorganizowane po raz pierwszy w sierpniu 2004 r. i mające się odbywać corocznie.

16 „Russia to deliver Su-33 fighters to China” - www.kommersant.com/p715509/r_528/China jet_fighters_export/ (wejście: 25.10.2006).

${ }_{17}$ Przy stosowaniu oficjalnego chińskiego przelicznika yuana do dolara, gdyż przy stosowaniu wskaźnika realnej siły nabywczej (PPP) Chiny wyprzedziły Japonię już w 1994 r. Wielu ekspertów twierdzi, że przelicznik yuana jest sztucznie zaniżony, podczas gdy japońskiego yena - sporo zawyżony. Nominalne przeliczniki w tym przypadku znacznie fałszuja rzeczywistość (red.).

18 We wrześniu 2006 r. Instytut Konfucjusza został uroczyście otwarty w Krakowie (red.) 


\section{KONCEPCJE: PODSTAWOWE PRZESŁANKI}

\section{Na czyją korzyść działa czas?}

Dwa podstawowe założenia legły u postaw nowej wielkiej strategii Pekinu. Pierwsza z nich to konstatacja, że przez ostatnie ćwierćwiecze Chiny przeżywają najdłuższy okres pokoju od połowy XIX w. Taki „okres strategicznych szans” (zhanlue jiyuqi) nie powtórzy się już nigdy, jeśli dopuści się do jego przeminięcia. Drugie założenie dotyczy przewidywanego stopniowego spadku strategicznego znaczenia Stanów Zjednoczonych, a wzrostu potęgi Chin. Występowanie zatem z konfrontacyjnymi wyzwaniami wobec supermocarstwa u szczytu jego potęgi byłoby bezsensowne, natomiast spokojne wyczekiwanie jest przejawem mądrości.

Choć opinie przeciwne do przedstawionej powyżej również pojawiają się w Pekinie, ścisłe kierownictwo zdecydowało się na wariant cierpliwego wyczekiwania. Wynika to głównie z przekonania o trwałości procesów wzrostu gospodarczego Chin.

\section{CHARAKTERYSTYKA NOWEGO PODEJŚCIA CHIN}

Chińska polityka zagraniczna od końca 2002 r. wykazywała dwie cechy: postawę asekuracyjną i rosnący stopień wewnętrznej koordynacji.

\section{Postawa asekuracyjna}

Motto obecnej chińskiej polityki zagranicznej brzmi: nie wybieraj się $w$ pojedynkę tam, gdzie masz do załatwienia coś nieprzyjemnego. Motyw ten występuje w trzech wariantach.

Po pierwsze, jeśli masz stawić komuś czoła - znajdź dla siebie jakiegoś partnera. Na przykład, gdy w czerwcu 2005 r., Pekin, w swoim sprzeciwie wobec rozszerzenia grona stałych członków Rady Bezpieczeństwa ONZ, znalazł sprzymierzeńca w Stanach Zjednoczonych. Chodziło mu przede wszystkim o kandydaturę Japonii, bliskiego sojusznika Waszyngtonu. Waszyngton zaś nie miał, oczywiście, nic przeciwko Japonii - lecz nie chciał zaakceptować Berlina, aspirującego do tej samej roli. Miesiąc później Chiny wraz z Rosją zażądały wspólnie, by Waszyngton wycofał się z baz w Azji Środkowej, do których dostęp uzyskał w 2001 r. w ramach wsparcia operacji w Afganistanie. Chinom i Rosji nie podobała się ta, jak ją odbierały oba państwa, ,ingerencja na ich podwórku”. Inne przykłady: Chiny przyłączyły się do protestów Korei Południowej wobec japońskiego uporu w oddawaniu czci swoim poległym na wojnach, m.in. zbrodniarzom wojennym z II wojny światowej. Na początku 2006 r. Chiny weszły z kolei w porozumienie z Rosja, by poprzeć prawo Iranu - nota bene głównego dostawcy ropy dla Chin - do rozwijania własnej energii jądrowej.

Po drugie: kryj się za plecami czołowego bojownika. Gdy Stany Zjednoczone przygotowywały się do inwazji na Irak, Chiny dbały o to, by trzymać się o pół kroku za Francją, Niemcami i Rosją krytykującymi plany wojenne Ameryki, i ani na chwilę nie 
przejęły inicjatywy. W połowie 2003 r., Stany Zjednoczone zwróciły się do Singapuru z prośbą, by jego okręty rozpoczęły patrolowanie Cieśniny Malakka, w której najczęściej dochodziło do napaści pirackich. Chiny, obawiając się odcięcia przez siły Stanów Zjednoczonych swojej jedynej drogi zaopatrzenia w rope, nie zgłosiły jednak obiekcji władzom w Singapurze. Zamiast tego, po cichu nawiązały kontakty z władzami Malezji i Indonezji, które wówczas głośno wyraziły swój sprzeciw wobec tej inicjatywy. W kwietniu 2004 r., po podpisaniu Regionalnej Inicjatywy dla Bezpieczeństwa na Morzu $^{19}$, Waszyngton oficjalnie zrezygnował z tego pomysłu.

Po trzecie: w każdym sporze koncentruj ataki na głównym obiekcie, a emabluj resztę. Taką strategię zastosowano wobec byłego premiera Japonii Junichiro Koizumiego ${ }^{20}$ i prezydenta Tajwanu - Chen Shui-biena. Obydwaj narazili się Pekinowi przejawami swego upartego nacjonalizmu. Chińskie władze starały się więc pozyskiwać sobie ludność obu krajów, ale także okazywano względy innym działaczom rządzących partii.

\section{Rosnący stopień wewnętrznej koordynacji}

Od 2003 r. widać po stronie władz ChRL coraz wyższy poziom koordynacji posunięć w różnych sferach stosunków ze światem zewnętrznym. Wymienić tu można ChALW, politykę wobec Tajwanu, jak też politykę inwestycji oraz zakupów zagranicą. Służą one nadrzędnym celom ogólnym: współpracy z USA, kultywowaniu dobrych stosunków z sąsiadami, ale też z Europa, Ameryką Łacińską i Afryką tak, by dalszy wzrost gospodarczy Chin mógł dokonywać się w pokojowym otoczeniu.

\section{a. ChALW}

Potencjał wojskowy Stanów Zjednoczonych - jedynego w tej chwili supermocarstwa - stanowi punkt odniesienia i aspiracji dla ChALW, ale zarazem traktowany jest jako przeciwnik, przeciwko któremu trzeba się przygotować. Tym niemniej także armia podporząqdkowała się wymogom strategicznym wyższego rzędu.

W styczniu 2003 r. generał Xiong Guangkai, ówczesny zastępca Szefa Sztabu ChALW, udzielił wywiadu organowi Centralnej Szkoły Partyjnej „Xuexi Shibao” (Study Times $)^{21}$, w którym wyraził pogląd, że partnerstwo chińsko-amerykańskie jest wśród zagranicznych spraw Armii najważniejszym priorytetem, wyższym niż współpraca chińskorosyjska. Jego wypowiedź korespondowała ze stwierdzeniami wspomnianego już wywiadu ówczesnego wice-premiera Qian Qichena z października 2002, o potrzebie posiadania nie tylko „ręki gotowej walczyć”, ale i drugiej „wyciagniętej do współpracy”.

Podobnych sygnałów było wiele. Na „Międzynarodowej Konferencji o Sztuce Wojny Sunzi”, która odbyła się w maju 2006 r. w mieście Hangzhou, na południu Chin, generał-major Zhang Shiping z Akademii Nauk Wojskowych stwierdził nawet:

${ }_{19}$ Szerzej na temat Regional Maritime Security Initiative zob.: http://www.globalsecurity.org/ military/ops/rmsi.htm

20 Nowym premierem Japonii został 26.09.2006 Shinzo Abe (red.).

21 Xiong Guangkai, Sanda guanxi jiao zhi tiaozhan jiyu bingcun (Three Main Relations Intertwines: Co-existence of Challenges and Opportunities), , Xuexi Shibao”, styczeń 2003. 
„[Powinniśmy] unikać konfrontacji ze Stanami Zjednoczonymi. Choć przejawiały one od dawna zapędy hegemonistyczne, nie jest wcale złą rzeczą przyjmowanie na swe barki przez Stany Zjednoczone dodatkowych ciężarów i zobowiązań wobec świata"22.

Dla wsparcia pekińskiej retoryki w polityce zagranicznej na temat „harmonijnego świata", ChALW wysłała na potrzeby misji pokojowych za granicą elitę swojego korpusu inżynieryjnego. Do połowy $2006 \mathrm{r}$. Chiny wysłały więcej żołnierzy w ramach pokojowych misji ONZ niż jakikolwiek inny z pięciu stałych członków Rady Bezpieczeństwa ${ }^{23}$.

\section{b. Polityka wobec Tajwanu}

Rozpoczęcie obecnie militarnej akcji przeciwko Tajwanowi byłoby równoznaczne z konfliktem z przepotężnymi siłami Stanów Zjednoczonych, co jest sprzeczne z przyjętymi obecnie głównymi celami strategicznymi. Rzucanie wyzwania jedynemu supermocarstwu u szczytu jego potęgi byłoby niecelowe. Choć liczba rakiet balistycznych krótkiego zasięgu rozmieszczonych po chińskiej stronie Cieśniny Tajwańskiej rosła stopniowo do ponad $800 \mathrm{w} 2006$ r., to jednak presja militarna Pekinu na Tajwan wyraźnie zelżała od roku 2003. Coroczne manewry ChALW w pobliżu Cieśniny Tajwańskiej mają odtąd mniejszy rozmach, a ćwiczenia pozorujące atak na tę Wyspę, choć wciąż są organizowane, przeniesiono w inne miejsca. Złagodzono także ton retoryki używanej przez Pekin.

Na przykład, od marca 2005 r. nie wspomniano już ani razu o zasadzie ,jeden kraj, dwa systemy”. Nie powtarzano też deklaracji: ,nigdy nie wyrzekniemy się możliwości użycia siły wobec Tajwanu"24. Od kwietnia 2005 r. Pekin z rzadka tylko napomykał o „zasadzie jednych Chin” i o „pokojowym zjednoczeniu” (z Tajwanem). Ich miejsce zajęła teraz retoryka ,pojednania” (hejie) 25 $^{25}$, pokojowego rozwoju” (heping fazhan). Poprzez wprowadzenie tego ostatniego terminu Pekin ujednolicił swą politykę wobec Tajwanu z całą swą polityką zagraniczną - jeśli nie zawsze w czynach, to przynajmniej w słowach. Wyeliminowano w ten sposób kłopotliwą sprzeczność między wojowniczym tonem wobec Tajwanu a przyjazną retoryką wobec reszty świata.

\section{EFEKTY NOWEJ STRATEGI W STOSUNKACH CHIN Z USA}

W drugiej połowie września 2004 r. ówczesny sekretarz stanu USA Colin Powell stwierdził podczas konferencji prasowej w Waszyngtonie, że w ciagu poprzedzających 9 miesięcy aż czterokrotnie spotykał się z Li Zhaoxingiem, ministrem spraw zagranicznych ChRL. Jakby to nie było wystarczającą ilustracją częstości kontaktów między

${ }^{22}$ Zhang Shiping, Zhongguo jueqi yu Zhong-Mei guanxi (The Rise of China and the SinoAmerican Relations). Przemówienie wygłoszone na wspomnianej konferencji.

23 Michael Fullilove, China Starts to Pull Its Weight at he UN, „International Herald Tribune” z 23.08.2006.

${ }^{24}$ Porównaj stare i nowe wytyczne dla polityki wobec Tajwanu Hu Jintao, prezydenta ChRL, z 4 marca 2005 i 16 kwietnia 2006.

25 Zhen Bijan, Zhongguo Gongchangdang zai 21 shiji di zouxiang (The Direction of the Communist Party in 21 Century), ,Renmin Ribao” (wydanie zagraniczne) z 22.11.2005. 
obu partnerami, Li dodał, że w tym samym okresie odbył 15 rozmów telefonicznych z Powellem ${ }^{26}$.

W istocie, oficjalne kontakty między Waszyngtonem a Pekinem sięgnęły bezprecedensowego poziomu w całej historii Chińskiej Republiki Ludowej od jej powstania w 1949 r., a być może nawet w całej historii wzajemnych stosunków, poczynając od pierwszych kontaktów Ameryki z Chinami za czasów dynastii mandżurskiej. W tym szybkim rozwoju stosunków można wyróżnić cztery cechy:

1. Wysocy funkcjonariusze państwowi obu krajów spotykają się znacznie częściej niż kiedykolwiek przedtem.

2. Spotkania te zostały zinstytucjonalizowane i odbywają się regularnie.

3. Obniżyła się i rozszerzyła ranga spotykających się przedstawicieli obu państw. Symboliczne spotkania głów państw w pompatycznej oprawie zastąpiły robocze spotkania w konkretnych kwestiach na szczeblu ministrów lub wiceministrów.

4. Wzrosła wreszcie bardzo różnorodność tematyki takich rozmów. Od spraw handlu partnerzy przeszli do kwestii wojskowości i programów kosmicznych.

W efekcie przełomowej wizyty w Pekinie (październik 2005) niezbyt wówczas entuzjastycznie do niej nastawionego sekretarza obrony USA Donalda Rumsfelda, oficerowie ChALW zostali w lecie 2006 r. zaproszeni w charakterze obserwatorów na ćwiczenia amerykańskiej Floty Pacyfiku. We wrześniu natomiast, obie strony zorganizowały wspólne manewry ratownictwa morskiego u wybrzeży Kalifornii, na wysokości San Diego. Również we wrześniu miała miejsce wizyta w Chinach Prezesa Zarządu NASA Michaela Griffina, który spotkał się tam z osobami kierującymi programami kosmicznymi i zwiedzał chińskie urządzenia kosmiczne. Wszystkie te wydarzenia miały charakter przełomowy, jeśli jeszcze nie co do treści, to z pewnością pod względem formalnym.

Uzupełniając, niejako, rozwój oficjalnych kontaktów, także wysiłki Pekinu włożone w zjednanie sobie zwykłych Amerykanów zdają się osiagać zamierzone rezultaty. Jak wynika z badania przeprowadzonego przez Pew Research Center, ogłoszonego 17 listopada 2005 r., znacznie mniejsza ich liczba niż jeszcze całkiem niedawno skłonna jest dostrzegać w Chinach przeciwnika ${ }^{27}$.

\section{JEJ SKUTKI DLA STOSUNKÓW ChRL Z JAPONIA}

8 października 2006 r. Shinzo Abe, nowy premier Japonii, odbył swoją pierwszą wizytę zagraniczną właśnie do Pekinu. Owo spotkanie przywódców obu krajów nadspodziewanie szybko spowodowało odwilż w stosunkach chińsko-japońskich. A pozostawały one w stanie lodowatym od sierpnia 2001 r., kiedy to poprzedni szef rządu Japonii - Junichiro

${ }^{26}$ Powell and China's Li Zhaoxing Discuss North Korea, Taiwan - Departament Stanu USA, Biuro Rzecznika, 30.09.2004. Li dodał wówczas: „gdyby istniała dyscyplina sportowa o nazwie „telefoniczne rozmowy ministrów spraw zagranicznych”, to pewnie już zdobylibyśmy złoto”.

${ }_{27}$ Badanie przeprowadzone miedzy 5.09 a 31.11.2005 r. wykazało, że 16\% Amerykanów wskazuje na Chiny jako źródło największego zagrożenia - w porównaniu do 32\% w 2001. 
Koizumi - odbył swoją pierwszą, z sześciu, wizyt w świątyni Yasukuni. Jest ona bowiem miejscem spoczynku 14 głównych japońskich zbrodniarzy z okresu II wojny światowej (straconych na podstawie wyroku Międzynarodowego Trybunału w Tokio - Red.). W geście protestu, Pekin odmówił wtedy dalszych spotkań z Tokio na najwyższym szczeblu. Atmosfera towarzysząca wizycie premiera Abe kontrastowała jaskrawo z wcześniejszymi opiniami, jakoby zamierzał on poprowadzić Japonię ku konfrontacji z Chinami ${ }^{28}$.

Przypomnieć można tu, że w listopadzie 2004 r. okręt podwodny klasy Han, należący do chińskiej marynarki wojennej, wtargnął na japońskie wody terytorialne. I tak nienajlepsze już stosunki japońsko-chińskie, popsuły się jeszcze bardziej. Rok 2005 i początek 2006 r. przyniosły tylko eskalację napięcia. W lutym 2006 r. były wysoki rangą urzędnik Pentagonu Dan Blumenthal, odnosząc się do stanu relacji między Chinami a Japonią miał więc powody, by powiedzieć, że jest „,bardziej zaniepokojony możliwym konfliktem na Morzu Wschodniochińskim niż w Cieśninie Tajwańskiej"29.

Warto w tym miejscu zwrócić uwagę, że w całym tym okresie pogarszających się stosunków oficjalnych, Pekin nie przestał kokietować zwykłych Japończyków i japońskich elit, poza samym Koizumim. A starał się ich zjednać za pośrednictwem najrozmaitszych zachęt ekonomicznych bądź z dziedziny polityki kulturalnej. Na przykład, w listopadzie 2005 r. rząd chiński i władze uniwersytetu Obirin obwieściły o porozumieniu dotyczącym otwarcia drugiego w Japonii Instytutu Konfucjusza ${ }^{30}$. Do początków 2006 r., z zaproszenia do odwiedzin w Pekinie skorzystało aż ośmiu byłych japońskich premierów, jak również całe grono emerytowanych ministrów, których przyjmowano niezmiernie wystawnie ${ }^{31}$, (pochodzących z tej samej Partii Liberalno-Demokratycznej - red.). Coraz większa liczba japońskich przedsiębiorców przenosiła się do Szanghaju, a liczba japońskich studentów w tym mieście wzrosła przez 10 lat - do października $2005 \mathrm{r}$. - dziesięciokrotnie ${ }^{32}$.

Przez 11 lat z rzędu, do roku 2003, Japonia była największym partnerem handlowym Chin, potem jednak spadła na trzecią pozycję $e^{33}$. Równolegle, w Japonii, zachodził odwrotny trend - wymiana handlowa z Chinami po 2004 r. osiagnęła poziom wyższy niż ze Stanami Zjednoczonymi. W miarę zacieśniania sieci wzajemnych zależności gospodarczych równowaga przechylała się coraz bardziej na korzyść Chin. Zależność Japonii od chińskiego rynku zbytu wyraźnie zwiększała się, podczas gdy Pekin był relatywnie

${ }^{28}$ Por. np. „Forbes” z 25.09.2006.

29 P. Parameswaran, Japan Says Managing Crisis With China Critical, AFP (Washington) z 13.02.2006.

30 Second Confucius Institute In Japan Set Up, www.chinanews.cn 2005-11-02 (wejście: czerwiec 2006).

31 Minyi fandui Koizumi kaolu jinnian bubai shenshe (Popular Opinion Objecting: Koizumi Considers Not To Visit the Shrine), „United Daily” z 14.06.2005, A4.

${ }^{32}$ H. W. French, N. Onishi, Economic Ties Binding Japan To Rival China, „New York Times” z 31.10.2005.

33 Strony internetowe MSZ ChRL: www.fmprc.gov.cn/chn/wjb/zzjg/yzs/gjlb/1281/default. html, (wejście: 25.10.2006). 
coraz mniej od niej zależny. Wielu obserwatorów przypisuje zresztą obecne ożywienie w japońskiej gospodarce właśnie rozwojowi handlu z Chinami. Taki kierunek zmian we wzajemnych stosunkach gospodarczych pozwolił Pekinowi na skuteczniejsze, poza-militarne, oddziaływanie na japońskie społeczeństwo.

Od połowy 2005 r. coraz liczniejsi przedstawiciele środowisk opiniotwórczych i wpływowych organizacji wyrażali sprzeciw wobec wizyt Koizumiego w świątyni Yasukuni. Znajdowali się wśród nich, na przykład, magnat medialny Tsuneo Watanabe (właściciel dziennika „Yomiuri Shimbun”), Nippon Izokukai - stowarzyszenie potomków żołnierzy pochowanych w świątyni, Kezai Douyukai - jedna z ważniejszych organizacji biznesowych i wiele innych ${ }^{34}$. W rezultacie w początkach $2006 \mathrm{r}$. nawet osoby z najbliższego otoczenia premiera zaczęły przejawiać niepewność w swoim poparciu dla jego wizyt w Yasukuni. Niektórzy wręcz dystansowali się od nich publicznie, jak minister spraw w zagranicznych Taro Aso, który w wywiadzie dla telewizji NHK dał do zrozumienia, że gdyby został premierem, mógłby zaprzestać ich kontynuowana. Były szef gabinetu Koizumiego, Yasuo Fukuda i minister finansów w jego rządzie, Sadakazu Tanikagi - obaj $\mathrm{z}$ widokami na fotel premiera - także wypowiedzieli się krytycznie w tej sprawie ${ }^{35}$.

Choć w ostatnich latach nastroje anty-chińskie w Japonii raczej się pogłębiły ${ }^{36}$, to Japończycy nauczyli się jednak oddzielać emocje od rozumu, i działać głównie tak, jak sugerują interesy. Według sondażu zamówionego przez japońskie MSZ w lutym 2006, aż 78\% respondentów pragnęło, by stosunki japońsko-chińskie uległy poprawie ${ }^{37}$. Do września 2006 r. rozmaite sondaże wykazywały wzrastający odsetek tych, którzy oczekiwali, że następny premier spełni to życzenie ${ }^{38}$. Wytwarzało to silną presję na Abe, by wraz z objęciem teki podjął kroki zmierzające do zamknięcia sprawy wizyt w Świątyni i poprawił stosunki z Pekinem. 11 września Abe zapowiedział, że jako przyszły premier nie będzie składał w Świątyni wizyt oficjalnych, ani informował czy i kiedy bywa tam prywatnie $^{39}$. Był to jednoznaczny odwrót od praktyk jego poprzednika, który zawsze informował o swoich wizytach, zarówno tych w charakterze premiera, jak i prywatnych.

34 Norimitsu Onishi, A Shadow Shogun Now Seeks the Spotlight, „International Herald Tribune” z 11-12.02. 2006, s. 1, 6; Minyi fandui Koizumi (Popular Opinion Objecting: Koizumi Considers Not To Visit the Shrine) „Dagong Bao” (Hong Kong) z 10.05.2006.

35 Christian Caryl, Revenge of the Doves, „Newsweek” z 6.02.2006, s. 23; H. Qingqing, Tanigagi qipao fancanbai Jingguo Shenshe (Tanigagi Announces to Run for Prime Minister Opposing Shrine Visit), „China Times” z 28.07.2006, A17.

${ }^{36}$ Pew Global Attitudes Project opublikowało wynik badania 21.09.2006, który wskazywał, że zaledwie18\% Japończyków określa swoje nastawienie wobec Chin jako pozytywne, w porównaniu do 55\% w badaniu z 2002 r. [w:] J. Kanter, Poll Finds China-Japan Tensions Up, „International Herald Tribune" z 22.09.2006, s. 3.

37 Wypowiedź Yuki Tatsumiego (Research Fellow w The Henry L. Stimson Center, Washington D.C.) podczas przesłuchania w House Committee on International Relations, na temat Japan's Relationship with Its Neighbors: Back to the Future? U.S House of Representatives, 14.09.2006.

${ }_{38}$ Tamże.

${ }^{39}$ An bei biao tai dang shouxiang bubai jinguo (Abe Announced that as Prime Minister He would not Visit the Shrine), „Apple Daily” ( Tajpej) z 12.09.2006, A 18. 
Po stronie Chin, prezydent $\mathrm{Hu}$ Jintao także zajął bardziej ugodowe stanowisko w sprawie wizyt w Yasukuni. Latem 2006 r. Pekin oznajmił, że chińskie obiekcje dotyczyły tylko wizyt premiera Japonii, co stanowiło pewne uelastycznienie dotychczas sztywnego stanowiska. Pod koniec września, prezydent ChRL wysłał do Tokio wiceministra spraw zagranicznych Dai Bingguo, w charakterze swojego osobistego przedstawiciela, by poinformować stronę japońską, że Hu przyjmie Abe bez wstępnego warunku publicznego wyrzeczenia się przezeń wizyt w Świątyni ${ }^{40}$. To zaś otworzyło drzwi do zaskakująco udanego szczytu japońsko-chińskiego z 8 października.

\section{PRZEJAWY NOWEJ STRATEGII W STOSUNKACH ChRL Z TAJWANEM}

Stosunki z Tajwanem zajmują trzecie miejsce w nowo wdrażanej przez Pekin wielkiej strategii. Z perspektywy Pekinu pilniejszą sprawą niż kwestia Tajwanu jest zapobieżenie destabilizacji wewnętrznej, jaka mogłaby osłabić obecny reżim, a nawet doprowadzić do jego upadku. W końcu dla Chin, dużo ważniejsze niż maleńki sąsiad z wyspy jest supermocarstwo - Stany Zjednoczone. Wreszcie, gdyby obecnemu chińskiemu kierownictwu nie udało się zapobiec ogłoszeniu przez obecne władze Tajwanu niepodległości de iure, polityczni konkurenci rządzącego ugrupowania mogliby je odsunąć od steru, chociaż nawet ewentualne potknięcia w stosunkach z tym krnąbrnym sąsiadem nie muszą prowadzić do aż tak niekorzystnych skutków.

A jednak Tajwan to dla kierownictwa ChRL najbardziej chyba zawikłany węzer ${ }^{41}$, z pośród tych, jakie ma on do rozwikłania. Jest tak poniekąd dlatego, że rozpatrując sytuację polityczną Tajwanu bardzo długo Pekin popełniał „błąd lustrzanego odbicia”. W demokratycznym Tajwanie siły działające od dołu są bardziej znaczące niż wpływy odgórne; mamy tam przecież rozpolitykowaną ludność, dynamiczny parlament i potężne media, a z drugiej słabnące kierownictwo kraju. W Chinach natomiast, gdzie sytuacja jest odwrotna, interpretowano sytuację na Tajwanie wedle własnej perspektywy. Dopiero w 1999 roku funkcjonariusze zajmujący się w ChRL sprawami tajwańskimi zaczęli w swoich analizach dostrzegać tę różnicę ${ }^{42}$. Jednak obowiązującą obecnie dyrektywę „,zjednywania serc i umysłów rodaków z Tajwanu” zaczęto przekładać na konkretne dzia-

40 „Yomiuri Shimbun” z 5.10.2006.

41 Używając określenia „zawikłany węzeł”/knotty problem/ nawiązuję do tytułu książki Richarda Busha, Untying the Knot: Making Peace in the Taiwan Strait, Washington D.C.: Brookings Institution Press, 2005. (Knot - knotty - naughty: nieprzetłumaczalna gra słów oparta na homofonii wyrazów „knotty” - zawęźlony, zasupłany - wymawia się tak, jak naughty - niegrzeczny, niesforny - od tłum.).

${ }^{42}$ Wicedyrektor Urzędu d/s Tajwanu Sun Yafu wyznał 27.04.2005 podczas „wewnętrznego” wykładu na Uniwersytecie Pekińskim, że w Pekinie do 1999 r. w ograniczonym stopniu rozumiano istotę stosunków poprzez Cieśninę. Yizhong fenqi Sun xiedi: renshi buzu, „Lienhebao” (United Daily News) z 29.04. 2005, A 4. 
łania dopiero w marcu 2005 r., gdy Hu Jintao oficjalnie przejął od ustępującego Jiang Zemina ostatnie ze stanowisk przezeń zajmowanych - przewodnictwo Centralnej Komisji Wojskowej ${ }^{43}$.

Obecny kształt polityki chińskiej wobec Tajwanu jest wynikiem skumulowanego doświadczenia grupowego, które gromadzili przywódcy cywilni i wojskowi od wczesnych lat 90 . Nie można przy tym nie docenić osobistego imprimatur, które na tejże polityce odcisnął wyraźnie sam Hu.

\section{Hu i Jiang - podstawowe różnice}

Ogólnie można powiedzieć, że podejście Hu Jintao jest dużo bardziej wszechstronne niż Jiang Zemina i charakteryzuje je większa dynamika. Polityka Hu różni się od jego poprzednika głównie w sześciu aspektach:

1. Brak kalendarza dla zjednoczenia. O ile Jiang zastanawiał się nad wyznaczeniem jakiejś ostatecznej daty zakończenia procesu unifikacji, choć ostatecznie nigdy jej nie ogłosił - Hu Jintao porzucił ten pomysł całkowicie. 24 września 2004 r., w pięć dni po przejęciu przewodnictwa w Centralnej Komisji Wojskowej KPCh, zaaprobował nową dyrektywę polityczną wobec Tajwanu: dązyć ze wszystkich sit do rozpoczęcia negocjacji, ale przygotowywać się też do podjęcia ataku i nie obawiać się tajwańskiej gry na zwtoke" (zhengqu tan, zhunbei da, bu pa tuo) ${ }^{44}$.

2. Położenie nacisku na działania poza-militarne. Hu kładzie większy nacisk na pozamilitarne środki oddziaływania włączając do nich - oprócz „trzech wojen”45 (prawnej, psychologicznej i medialnej) - także instrumenty ekonomiczne, społeczne, programy dla rolnictwa, politykę kulturalną i działania dyplomatyczne.

3. Od taktyki podwójnego uderzenia do tagodnej dominacji. Hu z jednej strony manifestuje jeszcze bardziej twarde stanowisko w „działaniach twardych”, ale i jego „miękka siła” jest jeszcze bardziej „miękka”. Na przykład „Ustawa Anty-secesyjna” (Anti-secession Laws - ASL), przyjęta przez OZPL 14 marca 2005 r., a więc już za rządów $\mathrm{Hu}$, teoretycznie autoryzuje działania o wiele ostrzejsze niż jakiekolwiek z proponowanych przez Jianga. Hu jednak, aby uczynić ją strawniejsza, połączył ją z wygłoszonym tuż przed jej przyjęciem ,przemówieniem dobrej woli" ${ }^{\prime 4}$, a następnie z serią gestów „dobrej woli” uczynionych tuż po tym fakcie. Między wiosną

43 19.09.2004, Jiang przekazał Hu przewodnictwo w Centralnej Komisji Wojskowej KPCh. Przekazanie towarzyszącego tej godności tytułu Przewodniczącego Państwowej CKW musiało zaczekać do dorocznej sesji OZPL, czyli do marca $2005 \mathrm{r}$.

${ }_{44} \mathrm{Na}$ podstawie rozmowy z naukowcem z Chin, 18.11.2004.

45 Xin xuedingde Jiefangjun zhengzhi gongzuo tiaoli banxing, „Jiefangjun Bao” z 15.12.2003.

46 Przemówienie Hu z 4.03.2005 miało znacznie łagodniejszy ton od tego, który dominował w ASL. Można było usłyszeć między innymi i takie słowa: „nie zaniechamy nigdy wysiłków dla osiagnięcia pokojowego zjednoczenia i nigdy też nie wyrzekniemy się zasady wierzenia w lud Tajwanu". 
2005 a jesienią roku następnego, Pekin skierował przynajmniej trzydzieści różnych pojednawczych inicjatyw adresowanych do ludności Tajwanu. Były wśród nich symboliczne dary (jak pandy), decyzja o otwarciu chińskiego rynku dla tajwańskich produktów rolnych, rozmaite stypendia dla studentów z Tajwanu, chcących pobierać nauki w Chinach kontynentalnych, itd.

4. Polityka aktywnych zabiegów o Kuomintang. Chociaż Jiang Zemin wolał Kuomintang (KMT) - dziś partię opozycyjną - od rządzącej pro-niepodległościowej Demokratycznej Partii Postępu (DPP), nigdy jednak nie podjął zabiegów o zjednanie sobie tej pierwszej. Hu zmienił to wyraźnie. Niedługo po przyjęciu ASL, w Pekinie po królewsku podjęto przewodniczącego KMT Lien Zhana, co dało początek regularnym spotkaniom przedstawicieli KPCh i KMT - przez dużą część $\mathrm{XX}$ w. będących zapiekłymi wrogami. Także przywódcy innych tajwańskich partii przychylnych idei zjednoczenia byli fetowani w Pekinie. W lipcu 2005 r. doszło nawet do tego, że Pekin oficjalnie przyznał, iż to generałowie Kuomintangu stoczyli więcej bitew w anty-japońskiej kampanii podczas II wojny światowej niż Armia Czerwona KPCh. Oznaczało to dramatyczne zerwanie z wcześniejszą oficjalną linią propagandową Pekinu.

5. Polityka pozytywnych gestów wobec DPP. Celem Hu jest zjednanie sobie większości społeczeństwa tajwańskiego i odizolowanie w ten sposób „twardego rdzenia” zwolenników idei niepodległościowej. O ile Jiang próbował angażować tamtejszych przedsiębiorców przeciwko funkcjonariuszom państwowym, albo przeciwstawiać zwykłych obywateli - władzom (yi shang wei zheng; yi min bi guan), Hu Jintao wydaje się nie mieć oporów wobec zabiegów o zjednywanie przychylności nawet w samym obozie DPP - choć partia ta jest uważana za pro-niepodległościową ${ }^{47}$.

6. Alternatywne koncepcje suwerenności. Nie decydując się na podanie tego do publicznej wiadomości, Hu Jintao zezwolił grupom-centrom analiz politycznych (thinktanks) i naukowcom chińskim na teoretyczne poszukiwania alternatywnych koncepcji suwerenności, które mogłyby przynieść przełom w impasie tajwańskim. Wśród takich pomysłów znalazły się, m.in. „nakładające się suwerenności”, „Stany Zjednoczone Republik Chińskich" (z odniesieniem do precedensu, gdy osobne miejsca w ONZ miały republiki sowieckie Ukrainy i Białorusi, obok ZSRR jako całości). Podczas szczytu APEC z udziałem prezydenta George'a W. Busha, Hu - sprzeciwiając się niepodległości Tajwanu de iure pośrednio uznał jego niepodległość de facto $^{48}$. Publiczne użycie tego poprzedniego sformułowania przez chińskiego przywódcę także było wydarzeniem bez precedensu.

${ }^{47} \mathrm{~W}$ przemówieniu z 4.03.2005 r. Hu stwierdził, że z otwartymi ramionami powita tych, którzy zrezygnują z popierania niepodległości, i że nie zamierza wnikać w ich poprzedzającą taki wybór przeszłość. Jiang odwrotnie - przyjmował, że ktoś raz określony jako zwolennik niepodległości nie będzie miał szans na poprawę.

48 Che Yuming and Chen Hegao, $\mathrm{H} u$ Jintao APEC hui Buxi qiangdiao taidu jiang duansong taihai heping (Hu Jintao Meets Bush and Stresses that Taiwan Independence Will Destroy the Peace across the Taiwan Strait), „Xinhua Report” z 20 listopada 2004. Zob.: www.xinhuanet.com (wejście: 22.10.2006). 
Formujacca się wielka strategia Chin...

\section{Hu i Jiang - podobieństwa}

Hu Jintao przejął jednak po Jiang Zeminie pewne dziedzictwo widoczne w czterech aspektach:

1. Militarne przygotowania do zajęcia Tajwanu. Hu popiera jednak szybką modernizację ChALW, mając na względzie jej użycie w ramach opcji militarnej, gdyby ostatecznie poza-militarne środki nie przyniosły oczekiwanych rezultatów. Liczba rakiet balistycznych krótkiego zasięgu rozmieszczonych nad Cieśniną Tajwańską osiagnęła 800 sztuk, co oznacza, że przybywało ich około 75 rocznie.

2. Sprzeciw wobec niepodleglości ważniejszy niż promowanie zjednoczenia. Hu przyjął w tym względzie rozkład akcentów po końcowym okresie rządów Jianga.

3. Hamowanie tajwańskich dażeń do niepodległości wykorzystując państwa trzecie. Także i w tym względzie Hu kontynuuje przyjęty przez Jianga po 1997 r. sposób działania. Polega on na wywieraniu nacisków na Tajpej poprzez Waszyngton i inne stolice, jak Paryż, Berlin, Singapur itd.

4. Ograniczanie pola międzynarodowej aktywności Tajwanu. Choć Hu Jintao nęcił Tajwan ewentualnym przyzwoleniem na przyznanie statusu obserwatora w Światowej Organizacji Zdrowia, Chiny nie zaprzestały zabiegów o wycofywanie uznania Tajwanu przez państwa dotychczas utrzymujące z nim stosunki dyplomatyczne.

\section{WYZWANIA NAPOTYKAJĄCE NOWA STRATEGIĘ}

Wyzwania, jakim Pekin musi stawić czoła przy stosowaniu tej nowej strategii można podzielić na dwa rodzaje, i to paradoksalnie przeciwstawne pod względem ich natury. Jedno - to rysowanie obrazu „Chin zagrażających”49, drugi zaś - „Chin nieudolnych”. Symptomatyczne w tym kontekście są zwłaszcza dwie sprawy:

1. Stany Zjednoczone ogłaszaja ,nowa strategie powstrzymywania”. Wprowadzanie przez Chiny w życie nowej wielkiej strategii odbywało się bez przeszkód między początkiem roku 2003 a wiosną 2005 r., gdy Stany Zjednoczone pochłonięte były wojną w Iraku. Potem jednak sprawy zaczęły przybierać inny obrót. Być może odegrało tu rolę dwa wydarzenia: podpisanie przez Indonezję i Chiny paktu o partnerstwie strategicznym (26.04.2005) i, nieco wcześniejsze, oświadczenie Alexandra Downera, ministra spraw zagranicznych Australii (dotychczas najwierniejszego sojusznika Stanów Zjednoczonych), że gdyby doszło do wybuchu kon-

${ }^{49}$ „Neewsweek” z 25.09.2006 zapytuje na okładce: Kto się boi Chin? ...W Wzyscy, i w tym problem. Jest to zwiastun artykułu Joshuy Coopera Ramo, An Image Emergency, s. 28-33. 
fliktu z Chinami w Cieśninie Tajwańskiej, poparcie jego kraju dla USA nie jest przesądzone ${ }^{50}$.

Wiosną 2005 r. Stany Zjednoczone zaczęły wprowadzać w życie politykę wobec Chin, nazwaną przeze mnie,„nową strategiąpowstrzymywania” (neo-containmentstrategy), a która oparta jest na trzech filarach. Pierwszy z nich, to nowe sojusze USA wśród sąsiadów Chin, budowane poprzez wizyty na wysokim szczeblu oraz oferty pomocy ekonomicznej i wojskowej. Kraje, które stały się obiektem tej operacji, to m.in. Mongolia, Uzbekistan, Pakistan, Indie, Wietnam oraz Indonezja. Po drugie, Pentagon redukując obecność wojskową $w$ wielu rejonach świata rozpoczął jednocześnie przenoszenie zaawansowanych technologicznie broni z Hawajów na Guam, a więc dużo bliżej Chin. Po trzecie wreszcie, Stany Zjednoczone wyraźnie zacieśniają militarną współpracę z Japonią. Oczywiście, nikt w Waszyngtonie zapytany oficjalnie nie przyznałby, że któryś z powyższych kroków był wymierzony w Pekin, tym nie mniej Chiny nie mogą ignorować faktów stanowiących dla nich nowe wyzwania.

2. Nuklearne awanturnictwo Korei Pótnocnej. W lipcu 2006 r., akurat podczas obchodów w Pekinie 45. rocznicy podpisania paktu o przyjaźni między ChRL a KRL-D, Korea Północna dokonała serii prób z rakietami balistycznymi. Chociaż Pekin podjął wiele wysiłków, by odwieść Phenian od przeprowadzenia tej potencjalnie destabilizującej cały region operacji. Sytuacja powtórzyła się w październiku, gdy trwała właśnie przełomowa wizyta w Pekinie Shinzo Abe, nowego premiera Japonii. Tym razem Kim Dzong-Il dokonał podziemnej próby z ładunkiem jądrowym. Był to kolejny policzek dla Pekinu, największego sojusznika, który wielokrotnie apelował do Kima, by nie narażał regionalnego bezpieczeństwa. Te wyzywające posunięcia Phenianu obnażyły w sposób bardzo ambarasujący dla Pekinu ograniczenia jego wpływów na swojego „satelite”. Co więcej, na szwank zostały wystawione nagle stabilność i pokojowe stosunki w regionie, na jakich opierał się stały rozwój gospodarczy Chin, a Pekin wyraźnie nie dysponował gotowymi do zastosowania środkami zaradczymi.

Działania Pekinu związane $\mathrm{z}$ wyżej zarysowanymi wyzwaniami, zwłaszcza w drugim wypadku, przyniosły mu zarówno pewne straty jak i korzyści. Do strat należałoby zaliczyć skazę na jaśniejącym dotąd wizerunku Chin, jako „wschodzącego mocarstwa" i bezbłędnego dyplomatycznego gracza. Jasno ukazała się przepaść między tym, jak je postrzegano, a jakie były ich rzeczywiste możliwości osiagania konkretnych wyników. Jako drugą stratę należałoby wskazać cios, być może śmiertelny, zadany idei nie rozwijania zbrojeń nuklearnych w Azji Północno-Wschodniej, jakiej Pekin sprzyjał mając na względzie swój długofalowy interes - zapewnienie stabilnych warunków dla wzrostu gospodarczego.

Z drugiej strony, Pekin zyskał jednak, gdyż zacieśnił współpracę z Waszyngtonem. Chiny poparły, na przykład, w Radzie Bezpieczeństwa ONZ obie rezolucje potępiające Phenian, a także sankcje przewidziane w drugiej z nich. 13 października 2006 r. zastępca

50 P. Symonds, Australian Foreign Minister Falls Off the Diplomatic Tightrope in Asia, World Socialist Web Site, 24.08.2004, http://www.wsws.org/articles/2004/aug2004/down-a24.shtml (wejście: 23.10. 2006). 
sekretarza stanu Christopher Hill określił poziom współpracy po koreańskich próbach nuklearnych jako „nie mający precedensu” ${ }^{51}$. W ten sposób Pekinowi udało się zmniejszyć znaczenie nowej strategii powstrzymywania i obejść ograniczenia przez nią narzucane przez zacieśnienie współpracy z USA. Dobry nowy początek zyskała także nowa polityka Chin wobec Tokio, a spotkanie na szczycie w październiku 2006 r. przywódców obu krajów wykroczyło prawdopodobnie dalej poza symboliczną wymowę niż jego architekci mogli zamarzyć.

Wydaje się, że Chiny stały się dojrzałym aktorem na scenie międzynarodowej, o czym świadczy powstrzymanie się od nazbyt ostrych reakcji wobec Korei Północnej, choć w tym wypadku rzeczywiście „utraciły one twarz”. Podtrzymały zatem swój sprzeciw wobec sankcji obejmujących żywność i wobec akcji zbrojnej przeciwko Korei Północnej, mimo że Kim nie na żarty zirytował Pekin. Podsumowując, Chinom szybko udało się stać „mocarstwem status quo”, wbrew dawniejszym zapowiedziom, że „pragną na zawsze pozostać krajem Trzeciego Świata" (według słów Deng Xiaopinga z lat 80 .). Chiny respektowały zatem ograniczenia, jakie przyjmuje odpowiedzialny międzynarodowy podmiot.

\section{SPOSTRZEŻENIA KOŃCOWE}

Na koniec można przedstawić garść spostrzeżeń.

1. Nowa wielka strategia, jak się zdaje, dobrze służyła dotąd Pekinowi w osiaganiu pozycji dającej realny wpływ na sytuację międzynarodowa, choć nie uniknięto pewnych porażek. Wśród nich na poczesnym miejscu znaleźć by się musiało nagłe wycofanie się Unii Europejskiej - chyba w dużej mierze w związku z przyjęciem przez Pekin Ustawy Anty-secesyjnej (ASL) - z planowanej decyzji o zniesieniu w 2005 r. embarga na handel bronią.

2. Nowy wyższy poziom zintegrowania różnych elementów w ramach nowej wielkiej strategii może pozwolić Pekinowi łatwiej odrabiać straty i łagodzić skutki porażek taktycznych.

3. Oficjalnie lansowane określenie „pokojowy wzrost” (peaceful rise) Chin (implikujące dochodzenie do pozycji wielkiego mocarstwa - Red.) miało krótki żywot: ledwo od listopada 2003 do marca 2004. Wielka strategia realizowana przez Pekin od końca 2002 r. stawia jednak te same zadania. Jest to w istocie polityka ,pokojowego wzrostu", choć bez używania obecnie tego terminu.

${ }^{51}$ Christopher Hill w National Press Club, Washington, D.C., powiedział, „...To, co wspólnie z Chinami udaje nam się osiągnąć w kwestii sąsiadującego z nimi państwa, nie ma precedensu. Być może więc za jakiś czas trzeba będzie w podręcznikach historii oddać sprawiedliwość Kim Dzong-Ilowi za to, że pchnął Chiny i Stany Zjednoczone we wzajemne objęcia”. V. Chang, Xier: MeiZhong hudong shiwu qianli (Hills: U.S.-PRC Cooperaton Unprecedented), „United Daily News", 15.10.2006, A14. 
4. Gdyby Pekinowi udało się utrzymać stabilność wewnętrzną w najbliższych dekadach, mógłby osiągnąc dominującą pozycję w Azji Wschodniej bez strat (lub przy zredukowaniu ich do minimum) i bez ofiar, jakie przynosi ze sobą wojna.

5. Świat, szczególnie sąsiedzi z regionu Azji i Pacyfiku, powinni baczniej śledzić stosowanie przez Pekin środków ze sfery ekonomicznej i polityki kulturalnej dla rozszerzenia swych wpływów, pamiętając jednak o pełnej entuzjazmu ChALW przyglądającej się temu z ubocza.

6. Pączkująca idea „dostosowania” (adjustment), nie będąca jeszcze w pełni teorią i daleka od stania się polityką, może stać się oficjalną doktryną Stanów Zjednoczonych określającą ich stosunki z Chinami, obok znanych koncepcji ,angażowania” (engagement) i ,powstrzymywania” (containment). Tyle tylko, że w przeciwieństwie do tych dwu ostatnich, scenariusz „dostosowania” nie przewiduje dla Stanów Zjednoczonych przywódczej roli.

7. Stany Zjednoczone powinny konsultować i koordynować z sojusznikami swoje stanowisko wobec nowej chińskiej wielkiej strategii.

8. Jednakże jeśli ostatecznie Stany Zjednoczone zechcą jakoś stawić czoła wzrostowi potęgi Chin, Tajwan byłby w tym niezbędny. Przy angażowaniu umacniających się Chin, Tajwan może służyć jako drogowskaz chińskiej demokracji. Jeśliby chciano by je powstrzymywać, Tajwan strzeże pierwszej wyspy z całego łańcucha. Zaś gdyby USA wybrały opcję dostosowania się do działań chińskich, Tajwan może występować jako swoisty bufor.

9. W interesie Europy leży, by Chiny umacniały się jako państwo działające konstruktywnie, pokojowe i demokratyczne. Demokratyczny Tajwan przypomina nieustannie Chińczykom z kontynentu pytanie: ,jeśli oni mogli to osiagnąć, dlaczego my nie możemy?" Choć Europę i Tajwan oddzielają ogromne przestrzenie, w tym aspekcie stoją one razem chcąc wspomóc te historyczne przemiany.

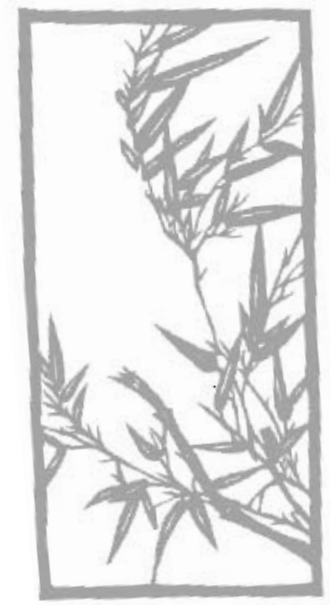


Formujacca się wielka strategia Chin...

\section{ZAŁĄCZNIK:}

OFENSYWA POJEDNAWCZA PEKINU WOBEC TAJWANU PO PRZYJECCIU USTAWY ANTYSECESYJNEJ (3.05.2005 - 18.10.2006)

\begin{tabular}{|c|c|c|c|}
\hline Lp. & Data & Wydarzenie & Źródło \\
\hline 1. & 3.05 .2005 & $\begin{array}{l}\text { Pekin ofiarowuje przebywającemu z wizytą } \\
\text { byłemu przewodniczącemu KMT - Lien Chanowi } \\
\text { - „trzy podarunki”: parę pand, decyzję o otwarciu } \\
\text { rynku kontynentalnego dla tajwańskich owoców } \\
\text { i usunięcie przeszkód powstrzymujących napływ } \\
\text { turystów z Chin kontynentalnych na Tajwan }\end{array}$ & $\begin{array}{l}\text { „China Daily” } \\
\text { (dalej: „CD”), } \\
\text { 4.05.2005, A1 }\end{array}$ \\
\hline 2 & 12.05 .2005 & $\begin{array}{l}\text { W Pekinie królewskie przyjęcie przewodniczącego } \\
\text { Partii Lud na Pierwszym Miejscu (People First } \\
\text { Party - PFP) Jamesa Soonga }\end{array}$ & $\begin{array}{c}\text { „Apple Daily” } \\
\text { (dalej: „AD”), } \\
\text { 13.05.2005, } \\
\text { A } 15\end{array}$ \\
\hline 3 & 24.08 .2005 & $\begin{array}{l}\text { Pekin ogłasza, że studenci z Tajwanu będą płacić } \\
\text { na kontynencie takie samo czesne za naukę, jak ich } \\
\text { koledzy z ChRL }\end{array}$ & $\begin{array}{c}\text { „United Daily” } \\
\text { (dalej: „UD”), } \\
\text { 24.08.2005, } \\
\text { A } 13\end{array}$ \\
\hline 4 & 28.08 .2005 & $\begin{array}{l}\text { Pekin uruchamia ponadto programy stypendialne } \\
\text { dla studentów z Tajwanu (po obniżeniu im już } \\
\text { czesnego) }\end{array}$ & $\begin{array}{l}\text {,UD”, } \\
28.08 .2005, \\
\text { A } 13\end{array}$ \\
\hline 5 & 7.09 .2005 & $\begin{array}{l}\text { Pekin zapowiada uelastycznienie systemu } \\
\text { udzielania kredytów przedsiębiorcom z Tajwanu }\end{array}$ & $\begin{array}{l}\text {,UD”, } \\
24.08 .2005, \\
\text { A } 13\end{array}$ \\
\hline 6 & 8.09 .2005 & $\begin{array}{l}\text { Pekin otwiera linię kredytową dla tajwańskich } \\
\text { przedsiębiorców w wysokości } 30 \text { miliardów } \\
\text { renminbi (yuanów) }\end{array}$ & $\begin{array}{c}\text { „China Times” } \\
\text { (dalej: „CT”), } \\
\text { 8.09.2005, } \\
\text { A } 13\end{array}$ \\
\hline 7 & 28.09 .2005 & $\begin{array}{l}\text { Pekin przedłuża dozwolony okres przebywania } \\
\text { w Chinach dla dziennikarzy z Tajwanu w trakcie } \\
\text { wykonywania zawodu }\end{array}$ & $\begin{array}{l}\text {,UD”, } \\
29.09 .2005 \\
\text { A } 13\end{array}$ \\
\hline 8 & 16.10 .2005 & $\begin{array}{l}\text { Pekin łagodzi restrykcje wobec Tajwańczyków } \\
\text { podejmujących pracę zarobkową w Chinach }\end{array}$ & $\begin{array}{c}\text { „Liberty } \\
\text { Times” } \\
\text { (dalej: „LT”), } \\
\text { 17.10.2005, } \\
\text { A } 2\end{array}$ \\
\hline 9 & 30.11 .2005 & $\begin{array}{l}\text { Pekin składa ofertę, by Tajwan zajął się organizacją } \\
\text { rozgrywek trzech dyscyplin olimpijskich w ramach } \\
\text { Olimpiady } 2008 \text { r. }\end{array}$ & $\begin{array}{l}\text {,AD”, } \\
30.11 .2005 \\
\text { A } 5\end{array}$ \\
\hline
\end{tabular}




\begin{tabular}{|c|c|c|c|}
\hline 10 & 10.12 .2005 & $\begin{array}{l}\text { Pekin ogłasza zamiar wydawania dokumentów } \\
\text { tożsamości }(I D \text { card) „rodakom z Tajwanu” }\end{array}$ & $\begin{array}{l}\text { „CT", } \\
10.12 .2005, \\
\text { A } 13\end{array}$ \\
\hline 11 & 19.12 .2005 & $\begin{array}{l}\text { Pekin obniża minimalne wymagania dla } \\
\text { kredytobiorców z Tajwanu, chcących skorzystać } \\
\text { ze wspomnianej linii kredytowej w wysokości } 30 \\
\text { mld RMB }\end{array}$ & $\begin{array}{l}\text {,UD”, } \\
19.12 .2005, \\
\text { A } 13\end{array}$ \\
\hline 12 & 9.02 .2005 & $\begin{array}{l}\text { Pekin wznawia eksport siły roboczej dla } \\
\text { tajwańskiego rybołówstwa }\end{array}$ & $\begin{array}{l}\text {,UD”, } \\
9.02 .2006, \\
\text { A } 13\end{array}$ \\
\hline 13 & 23.02 .2006 & $\begin{array}{l}\text { Pekin ogłasza gotowość do negocjacji z rządzącą } \\
\text { Tajwanem Demokratyczną Partią Postępu w } \\
\text { sprawie lotów charterowych dla chińskich } \\
\text { turystów }\end{array}$ & $\begin{array}{l}\text { „СТ", } \\
23.02 .2006, \\
\text { A } 13\end{array}$ \\
\hline 14 & 23.02 .2005 & $\begin{array}{l}\text { Pekin ogłasza zamiar wprowadzenia nowych } \\
\text { zasad dla turystyki w odniesieniu do mieszkańców } \\
\text { kontynentu pragnących odwiedzić Tajwan }\end{array}$ & $\begin{array}{l}\text {,UD”, } \\
23.02 .2006, \\
\text { A } 13\end{array}$ \\
\hline 15 & 6.03 .2006 & $\begin{array}{l}\text { Pekin ogłasza, że Tajwańczycy mogą brać udział } \\
\text { w życiu politycznym prowincji Fujian (z której } \\
\text { wywodzi się ich większość - Red.); uznano ją za } \\
\text { Specjalny Region do Spraw Tajwańskich }\end{array}$ & $\begin{array}{l}\text {,CT", } \\
6.03 .2005 \\
\text { A } 13\end{array}$ \\
\hline 16 & 6.032006 & $\begin{array}{l}\text { Przewodniczący Politycznej Konferencji } \\
\text { Konsultatywnej ChRL Jia Qinglin przedkłada } \\
\text { propozycję, by nawiązać dialog ze środowiskami } \\
\text { nieprzejednanych zwolenników niepodległości } \\
\text { wyspy }\end{array}$ & $\begin{array}{l}\text { „СT”, } \\
6.03 .2005 \\
\text { A } 13\end{array}$ \\
\hline 17 & 11.03.2006 & $\begin{array}{l}6 \text { ministerstw w Pekinie wydało rozporządzenia } \\
\text { podległym sobie służbom, aby otaczać opieką } \\
\text { Tajwańczyków, gdy na kontynencie znajdą się w } \\
\text { potrzebie }\end{array}$ & $\begin{array}{l}\text {,UD”, } \\
11.03 .2006, \\
\text { A } 13\end{array}$ \\
\hline 18 & 2.04 .2006 & $\begin{array}{l}\text { Pekin przyznaje kolejnym produktom rolnym z } \\
\text { Tajwanu zerową taryfę celną }\end{array}$ & $\begin{array}{c}\text { „CT", } \\
\text { 2.04.2006, A } 1\end{array}$ \\
\hline 19 & 16.04.2006 & $\begin{array}{l}\text { Podczas dorocznego Forum Komunistycznej Partii } \\
\text { Chin i Kuomintangu Pekin ogłasza } 15 \text { dziedzin } \\
\text { preferencyjnego traktowania Tajwańczyków }\end{array}$ & $\begin{array}{l}\text {,AD”, } \\
16.04 .2006, \\
\text { A } 1\end{array}$ \\
\hline 20 & 22.04 .2006 & $\begin{array}{l}\text { Pekin planuje zwiększyć import owoców i warzyw } \\
\text { z Tajwanu z dniem } 1 \text { maja }\end{array}$ & $\begin{array}{l}\text { „CT”, } \\
22.04 .2006, \\
\text { A } 17\end{array}$ \\
\hline 21 & 22.04 .2006 & $\begin{array}{l}\text { Pekin ustanawia strefy gospodarcze w prowincjach } \\
\text { nadmorskich dla tajwańskich farmerów }\end{array}$ & $\begin{array}{c}\text { „UD”, } \\
26.04 .2006, \\
\text { A } 13\end{array}$ \\
\hline
\end{tabular}




\begin{tabular}{|c|c|c|c|}
\hline 22 & 18.05 .2006 & $\begin{array}{l}\text { Pekin zezwolił na zatrudnienie Tajwańczyka jako } \\
\text { poborcy celnego w służbie ChRL }\end{array}$ & $\begin{array}{l}\text {,UD”, } \\
18.05 .2006, \\
\text { A } 13\end{array}$ \\
\hline 23 & 9.05 .2006 & $\begin{array}{l}\text { Pekin oferuje kolejne } 30 \text { mld RMB w linii } \\
\text { kredytowej dla tajwańskich przedsiębiorców oraz } \\
\text { nowe ułatwienia dla importu owoców z Tajwanu }\end{array}$ & $\begin{array}{l}\text { „UD”, } \\
9.05 .2006, \\
\text { A } 13\end{array}$ \\
\hline 24 & 9.05 .2006 & $\begin{array}{l}\text { Pekin zarządza kierowanie produktów morskich } \\
\text { z Tajwanu na błyskawiczną ścieżkę załatwiania } \\
\text { formalności celnych }\end{array}$ & $\begin{array}{l}\text {,UD”, } \\
9.05 .2006, \\
\text { A } 13\end{array}$ \\
\hline 25 & 1.06 .2006 & $\begin{array}{l}\text { Drugie Forum KPCh i KMT omawia sposoby } \\
\text { zabezpieczania interesów gospodarczych i } \\
\text { prawnych biznesmenów z Tajwanu }\end{array}$ & $\begin{array}{l}\text { „UD”, } \\
1.06 .2006, \\
\text { A } 13\end{array}$ \\
\hline 26 & 1.06 .2006 & $\begin{array}{l}\text { Pekin otwiera Kanton dla kontaktów z Tajwanem } \\
\text { na zasadach specjalnych dla rozszerzenia „Trzech } \\
\text { małych połączeń” }\end{array}$ & $\begin{array}{l}\text {,UD”, } \\
1.06 .2006, \\
\text { A } 13\end{array}$ \\
\hline 27 & 1.06 .2006 & $\begin{array}{l}\text { Pekin nadaje rolnym produktom z Tajwanu } \\
\text { preferencyjny status } \mathrm{w} \text { transporcie }\end{array}$ & $\begin{array}{l}\text { „UD”, } 1.06 . \\
2006, \text { A } 13\end{array}$ \\
\hline 28 & 10.06 .2006 & $\begin{array}{l}\text { Tajwańczycy z dokumentami podróżnymi } \\
\text { wydawanymi przez ChRL nie potrzebują już wiz } \\
\text { do Hongkongu }\end{array}$ & $\begin{array}{l}\text {,UD”, } \\
\text { 10.06.2006, } \\
\text { A } 13\end{array}$ \\
\hline 29 & 8.07 .2006 & $\begin{array}{l}\text { Kolejne propozycje kredytów dla przedsiębiorców } \\
\text { tajwańskich }\end{array}$ & $\begin{array}{l}\text { „CT”, } \\
8.07 .2006, \\
\text { A } 15\end{array}$ \\
\hline 30 & 27.07 .2006 & $\begin{array}{l}\text { Pekin pomaga tajwańskim przedsiębiorcom w } \\
\text { kłopotach finansowych na terenie ChRL, poprzez } \\
\text { ułatwianie działania bankom z Tajwanu }\end{array}$ & $\begin{array}{l}\text { „CT", } \\
27.06 .2006, \\
\text { A } 15\end{array}$ \\
\hline 31 & 27.07 .2006 & $\begin{array}{l}\text { Pekin przekazał dziewięciu miastom w prowincji } \\
\text { Fujian prawo do wydawania pięcioletnich } \\
\text { „dokumentów podróżnych” dla „rodaków z } \\
\text { Tajwanu” }\end{array}$ & $\begin{array}{l}\text {,UD”, } \\
27.07 .2006, \\
\text { A } 13\end{array}$ \\
\hline 32 & 27.07 .2006 & $\begin{array}{l}\text { Zarówno Najwyższy Sąd Ludowy, jak i Naczelna } \\
\text { Prokuratura Ludowa przygotowują uruchomienie } \\
\text { wydziałów spraw tajwańskich }\end{array}$ & $\begin{array}{l}\text {,UD”, } \\
27.07 .2006, \\
\text { A } 13\end{array}$ \\
\hline 33 & 18.10 .2006 & $\begin{array}{l}\text { Pekin otwiera linie kredytowe na sumę } 80 \text { mld } \\
\text { RMB dla tajwańskich rolników, którzy przenieśli } \\
\text { produkcję do Chin }\end{array}$ & $\begin{array}{l}\text { "AD”, } \\
18.10 .2006, \\
\text { A } 20\end{array}$ \\
\hline
\end{tabular}

